This item was submitted to Loughborough's Research Repository by the author.

Items in Figshare are protected by copyright, with all rights reserved, unless otherwise indicated.

\title{
Evaluation of the chemical and biomechanical viscoelastic properties of decellularised tracheal scaffolds [46]
}

PLEASE CITE THE PUBLISHED VERSION

https://doi.org/10.1016/j.jcyt.2017.02.050

PUBLISHER

(C) Elsevier B.V.

VERSION

AM (Accepted Manuscript)

\section{PUBLISHER STATEMENT}

This work is made available according to the conditions of the Creative Commons Attribution-NonCommercialNoDerivatives 4.0 International (CC BY-NC-ND 4.0) licence. Full details of this licence are available at: https://creativecommons.org/licenses/by-nc-nd/4.0/

\section{LICENCE}

CC BY-NC-ND 4.0

\section{REPOSITORY RECORD}

Belushi, H.K. Al, Lorenzo Zani, Yang Liu, Vadim V. Silberschmidt, M. Lowdell, and Simin Li. 2019. "Evaluation of the Chemical and Biomechanical Viscoelastic Properties of Decellularised Tracheal Scaffolds [46]". figshare. https://hdl.handle.net/2134/25973. 
EVALUATION OF THE CHEMICAL AND BIOMECHANICAL VISCOELASTIC PROPERTIES OF DECELLULARISED TRACHEAL SCAFFOLDS

H.K. Al Belushi ${ }^{1}$, L. Zani' ${ }^{2}$ Y. Liü ${ }^{2}$, V. Silberschmidt ${ }^{2}$, M. Lowdell ${ }^{3}$, S. Li $^{2}$

1. Haematology, Cancer institute, London, United Kingdom,

2. Wolfson School of Mechanical and Manufacturing Engineering, Loughborough University, Loughborough, United Kingdom,

3. Haematology, UCL, London, United Kingdom

Tracheal tissue engineering using decellularised extracellular matrix (ECM) scaffolds was one of the first fields to be clinically introduced to patients with phase I/II clinical trials underway in the UK. A key requirement in functional tissue engineering is to characterise the biomechanical properties of tissueengineered constructs relative to native tissues. This will provide baseline assessment of the initial functional state of the decellularised tissue. In the present study we explored the effect of decellularisation on the biochemical and mechanical viscoelastic properties of porcine tracheal cartilage. Viscoelasticiy describes the biphasic nature of cartilage attributed to its solid like composition of elastin and collagen fibrils and water trapped by glycosaminoglycans. This unique property helps prevent failure of cartilage under repetitive loading. Porcine tracheae were decellularised by vacuum assisted chemical enzymatic approach. Cellularity and key ECM components of the scaffolds were evaluated. And total DNA, glycosaminoglycan and collagen content were quantified. Dynamic mechanical analysis (DMA) frequency sweep test was used to assess the viscoelastic properties of tracheal cartilage. The results showed that decellularisation process removed most of the cellular contents with a signifi- cant reduction in total DNA content. There was no significant difference in the level of collagen and glycosaminoglycan content and the scaffolds retained most of the key extracellular matrix components. No significant difference observed in the viscoelastic storage modulus, loss modulus, complex modulus and tan delta. In conclusion, these results suggest that vacuum assisted chemical enzymatic decellularisation appeared to retain the critical structural and mechanical viscoelastic properties of tracheal scaffolds. 